\title{
New Criticism on the Competitiveness Concept: A Critical Review of the Concept at the Macroeconomic Level
}

\author{
Abdelmajid Charrass ${ }^{1}$ \\ ${ }^{1}$ University Mohammed V, Morocco \\ Correspondence: Abdelmajid Charrass, University Mohammed V, Morocco. Tel: 212-661-219-732. E-mail: \\ a.charrass@gmail.com
}

Received: October 26, 2016

Accepted: November 24, 2016

Online Published: December 18, 2016

doi:10.5539/ijef.v9n1p190

URL: http://dx.doi.org/10.5539/ijef.v9n1p190

\begin{abstract}
Competitiveness of nations has always been a subject of controversy regarding its validity. It is a concept surrounded by paradox, and it is widely used despite its conceptual fragility and the lack of a definition consensus. Moreover, this omnipresent concept in economic analysis is not included in any economic theory in the strict sense. Up to now, there is no theory of national competitiveness.

Despite the abundant publications about competitiveness, a critical review of competitiveness of nation has not yet appeared. This paper is proposed as a critical review of the concept of competitiveness at the nation's level, and it aims to examine the reasons that make this concept a point of controversy among economists.

This paper summarizes the rejection of the competitiveness concept in three points: Firstly, competitiveness is a microeconomic concept which gets deteriorated when applied to a nation, because nations do not compete like companies. Secondly, competitiveness is gained reputation in the political world; it is used without attention to explain success or defeat of an economy in a simplistic way. Today, the concept of national competitiveness is part of a hegemonic discourse. Finally, neither a definition consensus, nor an empirical evidence or a theoretical foundations, the national competitiveness appears such an international ideology rather than an economic concept. This doctrine is more evident with economic patriotism and the globalization that raises the frenzy of competition (Krugman, 1999).
\end{abstract}

Keywords: national competitiveness, critical review, concept, macroeconomic level

\section{Introduction}

It is an unwritten law that economists and politicians use the term "national competitiveness" in every speech about public policies; however, there is no consensus on its definition. Robert Z. Lawrence (2003) stated that "Competitiveness particularly with reference to an entire economy, is hard to define. Indeed competitiveness, like love or democracy, actually has several meaning" it appears that this word fill a need in the economic and political discourse Currently, defining competitiveness remains itself a research problem despite de abundant literature in this issue.

Competitiveness was born in the sphere of business in the 1980s and its success is quickly transmitted to macroeconomic and political areas. Although, the concept of competitiveness is controversial at macro level, it is welcomed in politics without any empirical verification and without any solid theoretical foundation. National competitiveness is taken as a postulate. Today, politicians swear only by competitiveness; they justify decisions by promoting national competitiveness. The political discourse provided strengthens to this fragile and meaningless concept (Krugman, 1999). Thus, national competitiveness manifests itself as an ideology more than an economic concept.

While the discourse on competitiveness of nations is gaining ground, a set of economists reject categorically the use of this concept at the macro level. In an ironic way asserts that any book of the international economy does not contain the word competitiveness on its index. Competitiveness at macro level is always qualified as "an unknown variable in economics" and a "poor relation of economic theory" (Debonneuil \& Fontagné, 2003), what is more, it is considered as a "soft underbelly of economics"; which leads to wonder, why these attacks for a concept widely used and highly publicized?

Therefore, this paper aims at explain the sources of contradiction and the essence of the debate about the validity 
of national competitiveness concept. It summarizes the rejection of the concept in three reasons: First, the discourse of competitiveness emerges as an ideology which is upheld by a strong current of economic patriotism; (economists and politicians support their country as their favorite football team). Second, Competitiveness is an exclusively microeconomic concept that should not be applied by analogy to the nation, because the nation does not work as firm. Lately the misuse of competitiveness concept by the media and politicians has increased vagueness around this concept.

\section{Method}

By examining the literature review of the concept of competitiveness, we have found three schools of thought about the concept of competitiveness: First, the school of competitiveness which considers this concept as a central theme of economic theory. Secondly, the quasi-competitiveness school asserting that competitiveness is a relative concept that can only have sense when it comparing the performance of nations. Finally, we have a on the school of non-competitiveness which categorically rejects the use of this concept at macroeconomic level. Thus, we examine critically the reasons for rejecting the concept of competitiveness to highlight the points of divergence around this concept and to summarize the causes of its rejection.

\section{Results \& Discussion}

A critical review of the literature shows that economists rejecting the concept of the competitiveness of nations often justify the impertinence of this concept by the following reasons:

\subsection{Competitiveness as a Contemporary Ideology}

The origin of the concept of competitiveness dates back at least to the 15th century (Reinert, 1995), and the first speech on competitiveness goes back to the theory of absolute advantage of Adam Smith as a synonym of economic success. The quest for performance and wealth makes this concept equivocal with infinity of interpretations. The global success of this concept is not due to its pertinence but in its systematic use in the political world as component of a hegemonic discourse. National competitiveness is the modernized expression which means the desire of economic power. Thus, competitiveness is an ideology rather than an economic concept.

Competitiveness is considered by its followers as a natural law, or the law of gravity. It is strongly supported despite the lack of supporting evidences (Rinehart, 1995). The systematic recourse to explain the economy through the prism of competitiveness increases misunderstanding and uncertainty around this concept. The modern design of competitiveness is related to distant issues, sociology, history, politics and culture.

Ideology generally defined as "a system of ideas and ideals, especially one which forms the basis of economic or political theory and policy" or "The set of beliefs characteristic of a social group or individual." (Oxford dictionaries) is characterized in the case of the ideology of competitiveness by two prominent features: First, this doctrine argues that all the difficulties of the economy come from a lack of competitiveness that generates unemployment, stagnation...Etc. It consider competitiveness as a "universal cure" that can solve the economic problems, and the concept of national competitiveness is used to justify economic policy, trade policy and business opposition to unions, reduced hours of work, wages increases (Rinehart, 1995). Second, the ideology of competitiveness supports the idea that the international economy is a confrontation field and rivalry space, a zero-sum game: The economy grows at the expense of another; this logic promotes the economic and the trade war. The economic patriotism and neo-liberalism are two philosophies that underlie the ideology of competitiveness.

Therefore, the concept of competitiveness is sacred and few economists opposed it. This ideology is fueled by a popular myth that generates a lot of fascination that consider economic world as rivalry space where every nation have to gain the battle. The ideology of competitiveness is defended by geo-economists in every nation and motivated by the "industry of ranking" which publishes an annual global report. Strongly, national competitiveness has gained the power of a universal law. Thus, the "Orthodoxy of competitiveness" is widely accepted, and attracts new supporters every day.

This ideology has evolved over three overlapping stages from a theoretical development to policy paradigms and then to "knowledge brand" (Diamond model, Indices, index, Council...Etc) that recognized worldwide. The ideology of competitiveness is a part of an "economic imaginaries".

\subsection{Competitiveness Is an Exclusive Microeconomic Concept}

Chikan (2008) defines the firm competitiveness as "the capability of a firm to sustainably fulfill its double purpose i.e. meeting customer requirements at profit". This capability can be realized by offering goods and 
services which customers value higher than those offered by competitors. According to Cetindamar and Kilitcioglu (2013), 'competitiveness is a capability and its potency has to be realized in firm's everyday operations'. It can be inferred from the above-mentioned definitions that a firm's competitiveness rests in its adaptability and its ability to realize long-run profit. An examination of the extant literature reveals that a wide variety of notions has been used for the three levels of competitiveness. There exists an ambiguity of all-encompassing conceptualization.

Competitiveness is a clear microeconomic concept that has undergone deteriorations when applied to the nation. The analogy between the firm and the nation is improper. And despite fascination with the term, many authors reject the application of the term at macro level. Debonneuil and Fontagné (2003) argues "Do not talk about national competitiveness to economists" and only the micro competitiveness concept is valid, the extension to macro level is misleading (Krugman, 1999).

The concept of competitiveness was confined to management, gradually invaded the analysis of international relations. This metaphor is the source of controversy, for example, United States and Japan are not competing in the same way as Coca Cola and Pepsi (Krugman. 1999) because "national economies do not go out of business such as uncompetitive firms". Furthermore, nations don't have a clear, well-defined and consensual bottom line to define it performance.

The success of the metaphor of competitiveness, which means that competition between nations have the same nature as firms, depends on its apparent intelligibility and its simplism. It has the ability to reduce the complex economic reality to the sample idea that the lack of competitiveness is the source of economic problems. The new "Industry of Ranking" widely publicized justifies the legitimacy of this concept at national level.

Competitiveness is a meaningless concept when applied to national economies. National competitiveness has not a well-defined bottom line and nations do not go out of business like firms. The concept of national competitiveness is elusive (Cellini, Soci, 2002). A less dogmatic doctrine says that the concept can have a meaning if it is considered as a relative concept for benchmarking of nations, a tool of comparison.

Certainly, the term competitiveness is one of the concepts that have undergone a continual metamorphosis. Etymologically, the sense slipped from cooperation to the competition, from the business to a term that is applied to the nation and the supranational group. Competitiveness' concept is primarily linked to competition; actually it is believed to explain welfare and living standards. Nowadays, the concept is still amorphous but its marketing still attractive.

\subsection{Politics, a Power Source of Competitiveness' Concept}

Since 1980, we have observed the rise of competitiveness as a major political issue in parallel to its development in the business world. Today it is extremely rare to hear a discourse on public policy without hearing repeatedly the word "competitiveness" (Hasset, 2011). Many economists argue that the term has a political nature and despite the fact that the term competitiveness is related to economy, it is surprising that this term does appear neither in economy's dictionaries nor in any manual glossaries, most used of micro and macro economy (Cellini, Soci, 2002).

Competitiveness is an exclusive micro economic concept developed by management theorists. However, the emergence of competitiveness applied to territory results from a transposition of the entrepreneurial discourse to politics where that receives an increased media interest. This transition to politic world is the source of marketing and metaphor of the concept of national competitiveness. The massive use of competitiveness' concept by politicians results from the ability of this term to fill the gap in the discourse of public policy.

The use of the concept is an "escape" from the real internal economic difficulties (Krugman, 1999). It is unwritten law that politicians answer by competitiveness in all questions about public policy, trade deficit or unemployment. The concept of national competitiveness is taken for granted as a ready-made way of thinking. Competitiveness concept is vague and ambiguous but wrapped up ingenuity by politicians and media.

Politics is the power's source of the term national competitiveness. Originally, this concept is neither economic nor geographic. Yet, it is essentially political (Krugman, 1999). Politicians have totally confidence in the term competitiveness. It is able to explain economic problems and justifies the existence of competitiveness' councils a as well as competitiveness' policies in most countries.

The global competitiveness rankings is shared by nations and widely publicized justifies the integration of this concept in public policy and today, it is present transversally in the political agenda. Today, in every country, there is a competitiveness council and related strategies. Both of them constitute the institutional side of national competitiveness, which justify the power and legitimacy of this concept. 


\section{Conclusion}

The concept of national competitiveness is widely used but it is controversial concerning its validity. The concept is rejected at the macro level by several economists for three major reasons: Firstly, the concept of competitiveness is used today as a natural law or the law of gravity (Rinehart, 1995), taken for granted and does not need to be proved or justified, which shows that competitiveness can be considered as an ideology more than an economic concept. Secondly, the concept of competitiveness has a microeconomic nature. It has a wide consensus at this level. However, the success of this concept in the business world stimulates "contamination" to other areas, particularly the sphere of nations. This transposition of firm's competitiveness to nation is the source of controversy. The concept of competitiveness suffered from serious deteriorations when applied to nations, because the analogy between firm and nation is false. National competitiveness has not a well- defined bottom line and nations do not go out of business like firms. Then, the concept of national competitiveness is elusive.Thirdly, the extensive use of the concept of competitiveness in the political sphere, as an unwritten law, when every discourse on public policy have to contain the term competitiveness to be easily accepted (Hassett, 2011). Politicians today swear only by competitiveness which it is seems that this term is politically motivated. The omnipresence of the concept of competitiveness in politics discourses exonerates it from any scientific examination. The concept of macroeconomic competitiveness draws strength from the political discourse and few economists manifest an opposition to this widely defended and supported concept. The global competitiveness rankings and "Industry on Competitiveness' Councils" (Krugman, 1999) gives a wide legitimacy to the concept.

The concept of national competitiveness has all conditions to survive and to develop despite its lack of theoretical fundamentals and consensus. It still resist to a fierce academic opposition and a harsh criticism. Its marketing remains attractive despite the skeptic around it. Nowadays, the rhetoric of national competitiveness' concept continues.

\section{References}

Cetindamar, D., \& Kilitcioglu, H. (2013). Measuring the competitiveness of a firm for an award system. Competitiveness Review, 23(1), 7-22. http://dx.doi.org/10.1108/10595421311296597

Chikan, A. (2008). National and firm competitiveness: A general research model. Competitiveness Review, 18(1), 20-28. http://dx.doi.org/10.1108/10595420810874583

Debonneuil, M., \& Fontagné, L. (2003). Compétitivité, Rapport du Conseil D’analyse Économique n40, Paris, La Documentation française.

Hasset, K. A., Hubbard, R. G., \& Jensen, M. H. (2011). Rethinking Competitiveness. American Enterprise Institute for Public Policy Research.

James, R. (1995). The Ideology of Competitiveness. Monthly Review, 47(5), 14. http://dx.doi.org/10.14452/MR-047-05-1995-09_2

Krugman, P. (1999). La mondialisation n'est pas coupable, vertus et limites de libre échange. Casbah Edition.

Lawrence, R. Z. (2003). Competitiveness. The Concise Encyclopedia of Economics. Library of Economics and Liberty. Retrieved September 13, 2014 from http://www.econlib.org/library/Enc1/Competitiveness.html

Porter, M. (1999). L'Avantage Concurrentiel des Nations. In la Concurrence selon PORTER. 1999. Paris: Edition Village Mondial.

Reinert, E. S. (1995). Competitiveness and its predecessors - A 500-year cross-national perspective. Structural Change and Economic Dynamics, 6, 23-42. http://dx.doi.org/10.1016/0954-349X(94)00002-Q

\section{Copyrights}

Copyright for this article is retained by the author(s), with first publication rights granted to the journal.

This is an open-access article distributed under the terms and conditions of the Creative Commons Attribution license (http://creativecommons.org/licenses/by/4.0/). 